${ }^{2}$ Fenech A, Hussey JK, Smith FW, Dendy PP, Bennett B, Douglas AS. The diagnosis of deep vein thrombosis using autologous indium ( ${ }^{111}$ In) labelled platelets. $\mathrm{Br} \mathrm{Med} \mathcal{F} 1981 ; 282: 1020-2$

${ }^{3}$ Albrechtsson U, Olsson C-G. Thrombotic side effects of lower-limb phlebography. Lancet 1976;i:723-4.

4 Mackie M, Bennett B, Ogston D, Douglas AS. Familial thrombosis: inherited deficiency of antithrombin III. Br Med f 1978;i:136-9.

${ }^{5}$ Albrechtsson U, Olsson C-G. Thrombosis after phlebography: a comparison of two contrast media. Cardiovasc Radiol 1979;2:9-18.

(Accepted 5 August 1981)

University Department of Medicine, Aberdeen Royal Infirmary, Aberdeen AB9 2ZB

J $H$ WINTER, MB, MRCP, lecturer

A FENECH, MD, MRCP, lecturer

B BENNETT, MD, MRCP, senior lecturer

A S DOUGLAS, DSC, FRCP, regius professor

\section{Osteomalacia in presence of "normal" serum 25-hydroxycholecalciferol concentration}

Measurement of serum 25-hydroxycholecalciferol (25-OHD) concentration is commonly thought to be of value in diagnosing osteomalacia, especially in doubtful cases. ${ }^{1}$ Preece $e t a l^{2}$ measured 25-OHD concentrations in patients with unequivocal osteomalacia and in no case was the concentration greater than $9 \mathrm{nmol} / \mathrm{l}(3.5 \mathrm{ng} / \mathrm{ml})$. Undetectable serum concentrations of 25-OHD have, however, been shown to occur in elderly subjects in whom osteomalacia had been excluded on histological, biochemical, and radiological criteria. ${ }^{3}$ We now report two cases of osteomalacia, diagnosed histologically, in which serum 25-OHD concentrations were close to the mean in elderly patients.

\section{Case reports}

\section{CASE 1}

A 74-year-old woman presented with a two-week history of aches and pains across the chest and increasing lassitude and fatigue. She had been housebound for many years because of a nervous disposition and had been taking pentobarbitone sodium regularly at night. Investigations showed serum calcium concentration, corrected for albumin and globulin, ${ }^{4} 1.06$ $\mathrm{mmol} / 1(4.2 \mathrm{mg} / 100 \mathrm{ml}$ ) (normal range for elderly women $1.22-1.66 \mathrm{mmol} / \mathrm{l}$ $(4 \cdot 9-6 \cdot 7 \mathrm{mg} / 100 \mathrm{ml})$ ), serum phosphate $0.58 \mathrm{mmol} / 1(1.8 \mathrm{mg} / 100 \mathrm{ml}$ ) (normal range for elderly women $0 \cdot 80-1.30 \mathrm{mmol} / 1(2 \cdot 5-4 \cdot 0 \mathrm{mg} / 100 \mathrm{ml}))$, and alkaline phosphatase 156 IU/1 (normal range 30-130 IU/1). Urea, electrolyte, and creatinine concentrations were within the normal range and there was no history of chronic renal disease. Radiography of the chest, spine, pelvis, and upper femora showed thin bones but no Looser's zones. Serum 25-OHD concentration measured five days after admission was $26 \mathrm{nmol} / 1(10.3 \mathrm{ng} / \mathrm{ml})$. Histological examination of a bone biopsy specimen showed osteoid seams covering most of the bony surface with up to five bright lines.

\section{CASE 2}

An 87-year-old woman presented with loss of appetite for six months and weakness of the legs for two months. Two weeks before presentation she had suffered two bad falls, after one of which she had developed pain in the jaw. She had been virtually housebound for the past three years because of her age, her dependent personality, and living up 15 stairs. Examination showed a bruise on the right side of the neck and tenderness posteriorly over the right ribs. Radiography showed a fracture through the ramus of the right jaw, multiple rib fractures, and symmetrical lesions on the medial aspects of both upper femora that had some of the features of Looser's zones.

Investigations showed corrected serum calcium concentration $1.28 \mathrm{mmol} / 1$ $(5.1 \mathrm{mg} / 100 \mathrm{ml})$, phosphate $0.89 \mathrm{mmol} / 1(2.8 \mathrm{mg} / 100 \mathrm{ml})$, and alkaline phosphatase $269 \mathrm{IU} / \mathrm{l}$. Urea, electrolyte, and creatinine concentrations were within the normal range and there was no history of chronic renal disease. Biochemical findings were not strongly suggestive of osteomalacia as calcium and phosphate concentrations were in the lower normal range, and the alkaline phosphatase activity may have been raised as a result of the multiple fractures. In view of the clinical and radiological features, however, serum $25-O H D$ concentration was measured and a bone biopsy performed. Serum $25-\mathrm{OHD}$ concentration on the day after admission was $15 \mathrm{nmol} / 1(6 \mathrm{ng} / \mathrm{ml})$. Histological examination of the bone biopsy specimen showed osteoid seams covering most of the bony surface with up to six bright lines.

\section{Comment}

The mean serum 25-OHD concentration in elderly women is 18 $\mathrm{nmol} / 1(7 \cdot 1 \mathrm{ng} / \mathrm{ml}),{ }^{5}$ and concentrations in both our patients were close to this. Our results, combined with those in the patients without osteomalacia in whom serum 25-OHD was undetectable, ${ }^{3}$ show that this measurement does not help either in making or excluding the diagnosis. As 25-OHD is not the active hormone this conclusion is not unexpected. Further work needs to be done to see whether measurement of the active hormone, 1:25 dihydrocholecalciferol, is more useful.

We thank Professor I Macintyre's laboratory for the 25-OHD measurements.

${ }^{1}$ Exton-Smith AN, Overstall PW. Guidelines in medicine: geriatrics. Vol 1. Lancaster: MTP Press, 1979

2 Preece MA, Tomlinson S, Ribot CA, et al. Studies of vitamin D deficiency in man. $Q 7$ Med 1975;44:575-89.

${ }^{3}$ Hodkinson HM, Hodkinson I. Range for 25 -hydroxy vitamin $D$ in elderly subjects in whom osteomalacia has been excluded on histological and biochemical criteria. Fournal of Clinical and ExperimentalGerontology $1980 ; 2: 133-9$

${ }^{4}$ Hodkinson HM. Biochemical diagnosis of the elderly. London: Chapman and Hall, 1977.

${ }^{5}$ Hodkinson HM, Bryson E, Klenerman L, Clarke MB, Wootton R. Sex, sunlight, season, diet and the vitamin D status of elderly patients. fournal of Clinical and Experimental Gerontology 1979;1:13-22.

(Accepted 12 August 1981)

Geriatric Unit, Department of Medicine, Hammersmith Hospital and Royal Postgraduate Medical School, London W12 0HS

KALMAN KAFETZ, BSC, MRCP, senior registrar in geriatric medicine H M HODKINSON, DM, FRCP, professor of geriatric medicine

\section{Crohn's disease presenting as recurrent pulmonary oedema}

Hypoproteinaemia is a well-recognised complication of Crohn's disease, ${ }^{1}$ especially when the disease is widespread, but the presentation of Crohn's disease as oedema from hypoproteinaemia is uncommon. Steinfeld $e t a l^{2}$ reported hypoalbuminaemia in nine out of 23 patients with Crohn's disease. Of 120 patients with Crohn's disease attending our gastroenterology clinic, 22 had hypoalbuminaemia $(<35 \mathrm{~g} / \mathrm{l})$ at diagnosis, of whom seven had oedema as one of the presenting symptoms.

We report on one of these patients, who presented with recurrent pulmonary oedema caused by hypoalbuminaemia, subsequently found to be due to small-intestinal Crohn's disease.

\section{Case report}

A 29-year-old man was admitted as an emergency in October 1974 after a week of acute dyspnoea, which had been waking him from sleep. His medical history included spinal tuberculosis at the age of 2 years, which had required several orthopaedic operations and left him with a residual spastic paraparesis and a dislike of both hospitals and doctors. He had had diarrhoea for one year, diagnosed as "colitis" by his general practitioner and treated with sulphasalazine (Salazopyrin), and recent vomiting and loss of weight. He was emaciated, with kyphoscoliosis, clubbing, pitting ankle oedema, and bilateral basal crepitations but no evidence of heart disease. Investigations showed normal blood count and plasma viscosity, urea and electrolyte concentrations, and cardiac enzyme activities. Chest radiography showed diffuse opacities throughout both lung fields, consistent with pulmonary oedema. This was thought to be due to heart failure of uncertain cause and was treated with frusemide with appreciable improvement. He declined further investigations and was discharged from hospital, only to be readmitted a few weeks later with similar symptoms. Chest radiography again showed opacities in both lung fields, most distinct in the lower zones. As before he refused further investigations and remained well until April 1975, when he required readmission. At this time he complained of loose stools and on examination had gross ankle oedema. Serum albumin concentration was 24 $\mathrm{g} / \mathrm{l}$ and total protein $47 \mathrm{~g} / \mathrm{l}$. Chest radiography showed no active lung lesion.

Two months later further investigations showed haemoglobin concentration $11.3 \mathrm{~g} / \mathrm{dl}$, mean cell haemoglobin concentration $30 \mathrm{~g} / \mathrm{dl}(30 \%)$, plasma viscosity $1.28 \mathrm{mPa} \mathrm{s}(1.28 \mathrm{cP})$, total protein concentration $36 \mathrm{~g} / 1$, albumin $20 \mathrm{~g} / \mathrm{l}$, and calcium $1.85 \mathrm{mmol} / 1(7 \cdot 4 \mathrm{mg} / 100 \mathrm{ml})$. Small-bowel barium studies 